\title{
DETERMINATION OF EXTRACTION TEMPERATURE AND PERIOD OF FISH OIL FROM TILAPIA (OREOCHROMIS NILOTICUS) BY PRODUCT USING WET RENDERING METHOD
}

\author{
Sugeng Heri Suseno*), Nurjanah*), Yoshiara, Saraswati \\ *Department of Aquatic Products Technology, Fisheries and Marine Science Faculty \\ Phone. (+62 251) 8622909-8622907, Fax (+62 251) 8622907
}

\begin{abstract}
Tilapia is a farmed commodity of freshwater fish that can be processed into refined products, e.g. the tilapia fillets. The arising problem in the utilization of tilapia into processed products is its residual waste. The purpose of study is to obtain fish oil from tilapia by-products by wet rendering extraction; to characterize fish oil; to determine the optimum temperature and period of wet rendering extraction; and to determine the fatty acid composition of fish oil. Extraction temperatures were varied i.e. $25,50,70$, and $90^{\circ} \mathrm{C}$. Extraction periods observed were $15,25,35$, and $45 \mathrm{~min}$. Quality parameters to evaluate the performance of fish oil were free fatty acid, acid value, peroxide, p-anisidine, total oxidation, and fatty acid composition analysis. The optimum temperature and period of wet rendering extraction were $70{ }^{\circ} \mathrm{C}$ for 35 minutes, with the highest yield of $6.44 \%$. Fish oil yield which was obtained using Bligh and Dyer method was $8.12 \%$. Fish oil extracted from wet rendering method contained $1.15 \%$ of EPA and $1.03 \%$ of DHA.
\end{abstract}

Keywords: by-product of tilapia (Oreochromis niloticus), extraction, fish oil, temperature, time

\section{INTRODUCTION}

Tilapia is an aquaculture commodity which has a prospective market. The market of tilapia products in processed form is triggered by high production of tilapia. Ministry of Marine Affairs and Fisheries, Republic of Indonesia (2013) stated that production of tilapia in Indonesia was 567,078 tonnes in 2011 , and 684,400 in 2012. Ready to process and ready to eat products from tilapia have quite high added value. Problem arising from the utilization of tilapia into processed products is residual waste. One example of the products is tilapia fillet. Production of fish fillets generates waste consisting of the head, tail, skin and viscera. Proportion of wastes or by products from processing of tilapia fillets can reach $70 \%$. Those by-products are still not used optimally. One of tilapia by-products development which have a good prospect in the market is fish oil.

Fish oil can be obtained by extraction. Extraction methods that are usually used are wet rendering and dry rendering method. Those methods do not require chemicals during process. Wet rendering is carried out with the addition of water, while the dry rendering is without the addition of water (Estiasih 2009). According to Yee (2007), the optimum temperature for wet rendering was $80{ }^{\circ} \mathrm{C}$. The objective of this study was to obtain optimum extraction temperature and period of wet rendering method to produce good quality fish oil. 


\section{MATERIALS AND METHODS}

\section{Materials and Equipment}

The main materials used for fish oil extraction were tilapia (Oreochromis niloticus) by products (head, viscera, and skin of tilapia) and distilled water as extraction solvent. Other materials were chemicals for characteristizing fish oil, such as distilled water, methanol $(\mathrm{MeOH})$, chloroform $\left(\mathrm{CHCl}_{3}\right)$, alcohol 96\%, phenolphtalein indicator, $\mathrm{KOH} 0.1 \mathrm{~N}$, isooctane, $\mathrm{p}$ anisidin reagent, glacial acetic acid, $\mathrm{Na}_{2} \mathrm{~S}_{2} \mathrm{O}_{3} 0.1 \mathrm{~N}, 1 \%$ starch indicator, $\mathrm{NaOH}, \mathrm{BF}_{3}$, saturated $\mathrm{NaCl}$, and $\mathrm{Na}_{2} \mathrm{SO}_{4}$ anhydrous.

Equipments used were container, knife, cutting board, food processor, funnels, Erlenmeyer glass, water bath CETROMAT WR, filter paper, centrifuge HIMAC CR21G, spectrophotometer Spectronic 20D+, rotary vacuum evaporator, burette, teflon tube lid, and, a gas chromatograph instrument SHIMADZU GC-2010 plus.

\section{Methods}

Tilapia (Oreochromis niloticus) was purchased from Caringin traditional markets, Bogor, West Java, Indonesia and then brought to the laboratory aliv in plastic containers using ice and water as media. Fish was washed, and then dressed to separate meat and by products. Tilapia's head, viscera, and skin were homogenized and then stored at $-20^{\circ} \mathrm{C}$.

Homogenized by-product was added with distilled water at a ratio of 1:1. Wet rendering extraction was done in two temperature categories, namely low temperature of 25 ${ }^{\circ} \mathrm{C}$ and $50{ }^{\circ} \mathrm{C}$, and at high temperature of $70^{\circ} \mathrm{C}$ and $90^{\circ} \mathrm{C}$, combined with extraction periods of $15,25,35$, and $45 \mathrm{~min}$. Extraction was carried out using a boiling technique. After each combination of wet rendering extraction treatments was implemented, the boiled sample was then filtered to obtain a liquid fraction. The liquid fraction was centrifuged to separate water and oil fractions.

As a comparison, an extraction using Bligh and Dyer method was employed. $5 \mathrm{~g}$ sample was inserted into the erlenmeyer and added by $20 \mathrm{~mL}$ of methanol $(\mathrm{MeOH})$ and $10 \mathrm{~mL}$ of chloroform $\left(\mathrm{CHCl}_{3}\right)$. Mixture of sample and solvent was homogenized using vortex mixer for 2 minutes. Solution was added as much as $10 \mathrm{~mL} \mathrm{CHCl} 3$ and shaken for 2 minutes. Then, it was added as much as $18 \mathrm{~mL}$ of distilled water and shaken with a vortex mixer for 2 minutes. Solution was formed into two phases, and separated using a separating funnel. Chloroform was evaporated to obtain oil using a rotary evaporator at $45^{\circ} \mathrm{C}$.

Extracted fish oil was then chemically analysed to evaluate its quality. Quality parameters observed were free fatty acids (free fatty acid) (AOAC 2005); acid value (AOAC 2005); peroxide value (AOAC 1995); anisidine value (IUPAC 1987); totox value (AOAC 1995); and fatty acid profiles using gas chromatography (AOAC 2005). 


\section{RESULTS AND DISCUSSION}

\section{Chemical Composition of Tilapia By Product}

Result of proximate analysis showed that tilapia by product had $64.58 \%$ moisture content, $3.01 \%$ ash content, $12.98 \%$ fat content, and $13.24 \%$ protein content (Figure 2). Fat content of tilapia by-product are higher than that of tilapia meat. Goddess and Ibrahim (2008) stated that fat content of tilapia meat was $1.01 \%$.

\section{Yield of Fish Oil}

The yield of fish oil which was obtained using Bligh and Dyer method was higher than the one extracted using wet rendering method (Figure 3). Yield of fish oil from Bligh and Dyer extraction was $8.12 \%$, while the wet rendering extraction with 16 combinations of different extraction temperature and period was in the range of $1.49-6.44 \%$. The above results showed that extraction using a combination of different extraction temperature and period could not maximally extract oil.

Bligh and Dyer method was performed using chemical solvent to extract the total fat in fish. Polar solvent will penetrate into the cells and extract the lipids from the cell membrane to be converted into phospholipid material (Bligh and Dyer 1959). Fish oils which are extracted by this method can be used as a control to estimate how much fish oil can be extracted from the sample.

Result showed that the fish oil yield increased with the increasing of extraction temperature. Decrease in yield percentage occured at $90{ }^{\circ} \mathrm{C}$ was probably due to the oxidation process. Wu and Peter (2008) stated that there are physical factors that can affect the production of fish oil, one of which is processing temperature. High temperature can cause the oxidation process resulting in fat breakdown. Ahren and Klibanow (1985) noted that proteins usually undergo irreversible denaturation when heated at 90-100 ${ }^{\circ} \mathrm{C}$. Denatured proteins forming a dense structure can cause inhibition of oil release. Yee (2007) showed that the yield of extracted fish oil increased from $60{ }^{\circ} \mathrm{C}$ to $80{ }^{\circ} \mathrm{C}$, but decreased at extraction temperature of $100{ }^{\circ} \mathrm{C}$.

Based on the statistical analysis $(P<0.05)$, different extraction period did not affect the yield of fish oil. The longer extraction period will be more effective to split adipose cell which contain lipids, so the yield of extracted lipid is great (Estiasih 2009). Extraction which is performed for 15 minutes produced a lower yield, due to incompletely split of adipose cells.

\section{Quality of Fish Oil}

\subsection{Free Fatty Acids (FFA)}

Free fatty acid content of fish oil from each extraction treatment can be seen in Figure 5 . The higher extraction temperature was resulting in fish oil with higher FFA value. FFA values decreased accordiningly with increasing extraction temperatures. Fish oil with the lowest FFA value could be extracted at $90{ }^{\circ} \mathrm{C}$ for 25 minutes. Khoddami et al. (2009) informed that increasing extraction temperature can cause faster formation of free radicals and free fatty 
acids. High extraction temperature could trigger the onset of FFA impairment, in which free fatty acids were degraded into volatile components (Weber et al. 2007). Furthermore, high extraction temperature induces denaturation of lipase in the cooked samples. It will prevent the release of free fatty acid component (Weber et al. 2007). Chantachun et al. (2000) also found in his study that low value of FFA obtained from tuna oil extracted using at $95^{\circ} \mathrm{C}$.

Differences of extraction temperature affected the free fatty acid value in fish oil, while the different extraction period did not affect FFA value $(P<0,05)$. FFA content of the overall combinations of extraction temperature and period was in the range of $3.85-7.15 \%$. Standard FFA value in fish oil according to the International Association of Fish Meal and Oil Manufacturers (IFOMA) (1981) is in the range of $1-7 \%$ oleic acid. FFA values for all fish oil obtained in this study were within the IFOMA standard.

\subsection{Acid Value (AV)}

Extraction period did not affect acid value, but the extraction temperature significantly ( $P$ $<0.05$ ) affected the acid value (Figure 6 ). The acid value decreased with increasing of extraction temperature. Acid value of all combination treatments was ranged between $6.54 \%$ to $12.15 \%$. Acid value indicates the formation of free fatty acids because of oil hydrolysis (Panagan et al. 2011). According to The International Fish Oil Standard (IFOS) (2011), acid value in fish oil should be less than $2.25 \mathrm{mg} \mathrm{KOH} / \mathrm{g}$. The acid values of all extracted fish oil were above IFOS.

Oil and fat hydrolysis produce free fatty acids and glycerol. Hydrolysis may occur due to the presence of water (Estiasih 2009). Water that evaporated because of heating process can reduce the hydrolysis of the oil. $\mathrm{AV}$ of the oil extracted at $90{ }^{\circ} \mathrm{C}$ decreased due to reduction of avalaible water in the oil.

\subsection{Peroxide Value (PV)}

Extraction period did not affect peroxide value of the oil, but the temperature significantly $(P<0.05)$ influenced peroxide value (Figure 7$)$. The higher temperatures, the greater peroxide value will be. However, the result showed that peroxide value of the oil extracted at $25{ }^{\circ} \mathrm{C}$ and $90{ }^{\circ} \mathrm{C}$ were not significantly different. It means the peroxide value increased with the elevating of temperature, but the value decreased when extraction was conducted at $90{ }^{\circ} \mathrm{C}$. According to IFOS (2011), PV should not be exceeding $3.75 \mathrm{meq} / \mathrm{kg}$. PV of all extracted fish oil have been higher than IFOS.

Peroxide formation is occured during primary oxidation. Fish oil contains high number of unsaturated fatty acid, so it is easily oxidized to become rancid. Rancidity protracted will form peroxides and decrease the quality of the fish (Damongilala 2008). The unpleasant rancid odor due to the formation of aldehydes or ketones as derived products of hydroperoxides. The oil/fat breakdown led to the formation of free radicals caused by light, heat, fat peroxide, heavy metals, hematin, hemoglobin, and several other causes. Free radicals can react with oxygen to form peroxide compounds which ultimately affect the physical and chemical properties of the oil (Estiasih 2009). 
Heat affects the initiation of autooxidation process. High temperature exposure to the sample will be resulting in high content of peroxides. Result showed that the decreasing of peroxide value occured when extraction was carried out at $90{ }^{\circ} \mathrm{C}$ probably also due to fewer oxygen dissolved in the material. If the water temperature raised, dissolved oxygen will decrease. Temperature increase can cause water molecules move more quickly, thus it can destroy the hexagonal structure and release the trapped oxygen. The critical point will occur at a temperature of $100{ }^{\circ} \mathrm{C}$, when it is no longer dissolved oxygen. Free radicals can trigger the formation of peroxides when it reacts with oxygen. Extraction temperature at $90{ }^{\circ} \mathrm{C}$ could make the material lost much dissolved oxygen.

\subsection{Para-anisidine Value (pAV)}

Extraction temperature and period significantly $(P<0.05)$ affected $p$-anisidine value of the oil (Figure 7). Extraction at $25{ }^{\circ} \mathrm{C}$ gave significant different $\mathrm{p}$-anisidine value compared with three other extraction temperatures. Meanwhile, extraction at $50{ }^{\circ} \mathrm{C}, 70{ }^{\circ} \mathrm{C}$, and $90{ }^{\circ} \mathrm{C}$ produced fish oil having insignificant difference of $p$-anisidine values. The lowest $p$-anisidine value was found in fish oil extracted at the treatment of $25^{\circ} \mathrm{C}$. According to IFOS (2011), panisidine value should be less than $15 \mathrm{meq} / \mathrm{kg}$. Overall $\mathrm{p}$-anisidine values of fish oil obtained in this study was still in the range of standard set by the IFOS.

Hydroperoxide decomposition will produce secondary oxidation products such as aldehydes, ketones, acids, alcohols, hydroxy component, lactones, hydrocarbons, dienal, epoxide monomer and polymer compounds, etc. Secondary oxidation product is measured as p-anisidine value (Panagan et al. 2011 ).

Lowest $\mathrm{p}$-anisidine value could be found in oil extracted at $25{ }^{\circ} \mathrm{C}$. Extraction period affected the p-anisidine value. The longer extraction time, the higher $\mathrm{p}$-anisidine value will be. Longer time of extraction period will bring about the maximum decomposition of hydroperoxides leading to generate secondary oxidation products (Estiasih 2009).

\subsection{Total Oxidation (Totox)}

Temperature significantly $(P<0.05)$ affected total oxidation value of the oil (Figure 8 ). The higher extraction temperature would produce fish oil with greater totox values. Totox value impaired when the extractio temperature employed was $90{ }^{\circ} \mathrm{C}$, but the value was insignificantly different from the value of the oil extracted at $50{ }^{\circ} \mathrm{C}$ and $70{ }^{\circ} \mathrm{C}$. According to IFOS (2011), the maximum totox value of fish oil is $20 \mathrm{meq} / \mathrm{kg}$. Totox value of all extracted fish oil have been exceeding the standard set by IFOS.

\subsection{Fatty Acid Composition}

Physical and chemical properties of fish oil are affected by the type of fish oil fatty acid composition (Estiasih 2009). Fatty acid profilling was carried out for the fish oil extracted at $25{ }^{\circ} \mathrm{C}$ and $70{ }^{\circ} \mathrm{C}$ for 35 minutes (Table 1). Extraction period of 35 minutes gave the highest yield. Extraction period generally had no effect on chemical characteristics of the fish oil.

DHA and EPA contents decreased with increasing extraction temperature. EPA and DHA have some double bonds being susceptible to oxidative rancidity, which can be enhanced by 
high temperature exposure. Furthermore, high temperature can cause the hydrolysis of fatty acid, so it implies on a changes in fatty acid composition. EPA and DHA contents of the extracted fish oil were significantly higher compared to fish oils which were extracted from Oreochromis niloticus, Clarias gariepinus, Tiilapia zilli (Osibona et al. 2009) and Clarias gariepinus (Panagan et al. 2011 ) (Table 2).

\section{CONCLUSIONS}

Production of processed tilapia generated by-product, which can be used as raw material for producing fish oil. The yield of fish oil obtained through wet rendering method was $6.44 \%$. FFA values, AV, peroxide value, $p$-anisidin value, and total oxidation value of extracted fish oil were still below standard set by IFOS, therefore the oil needs further purification or refining process. The recommended method to process tilapia by-product into fish oil was by extraction at $70^{\circ} \mathrm{C}$ for 35 minutes.

\section{Acknowledgement}

Completion of this paper would not have been possible without the assistance and support of many people. To them I would like to convey my heartfelt gratitude and sincere appreciation

\section{REFERENCES}

Ahren TJ, Klibanow AM. 1985. The mechanism of irreversible enzyme inactivation at $100^{\circ} \mathrm{C}$. $J$ Science, 228: 1280-1284.

AOAC. 1995. Official Method of Analysis. Virginia (US): Association of Analytical Chemist, Inc. AOAC. 2005. Official Method of Analysis. Virginia (US): Association of Analytical Chemist, Inc.

Bligh EG, Dyer WJ. 1959. A rapid method of total lipid extraction and purification. J Biochemistry and Physiology, 37:911-917.

Chantachun S, Benjakul S, Sriwirat N. 2000. Separation and quality of fish oil from precooked and non-precooked tuna heads. J Food Chemistry 69: 289-294.

Damongilala L. 2008. Kandungan asam lemak tak jenuh minyak hati ikan cucut botol (Cenctrophorus sp) yang diekstraksi dengan cara pemanasan. J Ilmiah Sains 8(20):249253.

Dewi EN, Ibrahim R. 2008. Mutu dan daya simpan fillet dendeng ikan nila merah yang dikemas hampa udara dengan vacuum sealer skala rumah tangga. I Saintek Perikanan $4(1): 15-17$.

Estiasih T. 2009. Minyak Ikan, Teknologi dan Penerapannya untuk Pangan dan Kesehatan. Yogyakarta: Graha llmu.

IFOMA. 1981. Method of Analysis for Chemistry Value of Fish Oil. England: Hoval Lane, Orchad Parade, Mutton Lane PN6 3AR.

IFOS. 2011 . Fish oil purity standars. http://omegavia.com (Accesed August, 30, 2013).

IUPAC. 1987. Standart Method for The Analysis Of Oils Arld Fats and Derivatives. $7^{\text {th }}$ Edn. Paquot C., A. Hautfebbe (Eds). Oxford: Blackwell Scientific Publishing Ltd.

Khoddami A, Arifin A, Bakar J, Ghazali HM. 2009. Fatty acid profile of the oil extracted from fish waste (head, intestine and liver) (Sardinella lemuru). J World Applied Sciences $7(1): 127-131$.

Ministry of Marine Affairs and Fisheries, Republic of Indonesia, 2013. Tilapia production in Indonesia. http://kkp.go.id (Accesed August, 30, 2013).

Osibona A, Kusemiju K, Akande GR, 2009. Fatty acid compotition and acid profile of two freshwater species, African catfish (Clarias gariepinus) and tilapia (Tilapia zilli). J Food Agriculture Nutrition and Development 9(1):608-621. 
Panagan A, Heni Y, Jojor UG. 2011. Analisis kualitatif dan kuantitatif asam lemak tak jenuh omega-3 dari minyak ikan patin (Pangasius pangasius) dengan metoda kromatografi gas. J Penelitian Sains 14(4):38-42.

Weber J, Bochi VC, Ribeiro CP, Victorio AM, Emanuelli T. 2007. Effect of different cooking methods on oxidation. J Food Chemistry 106:140-146.

Wu TH, Peter JB. 2008. Salmon by-product storage and oil extraction. J Food Chem $111(08): 868-871$.

Yee TH. 2007. Influence of extraction temperature and time on yield and quality of oil recovered from Tilapia (Oreochromis niloticus) by product [Thesis]. Malaysia: University Sains Malaysia.

\section{Attachment}

Table 1 Fatty acid composition of fish oil from tilapia by product

\begin{tabular}{|c|c|c|}
\hline \multirow[t]{2}{*}{ Fatty Acid Composition } & \multicolumn{2}{|c|}{ Area $(\% \mathrm{w} / \mathrm{w})$} \\
\hline & $25^{\circ} \mathrm{C}$ & $70^{\circ} \mathrm{C}$ \\
\hline Lauric Acid, C12:0 & 0.08 & 0.10 \\
\hline Tridecanoic Acid, C1 3:0 & 0.04 & 0.05 \\
\hline Myristic Acid, C1 4:0 & 3.80 & 3.92 \\
\hline Pentadecanoic Acid, C15:0 & 0.69 & 0.77 \\
\hline Heptadecanoic Acid, C17:0 & 1.23 & 1.27 \\
\hline Stearic Acid, C18:0 & 4.15 & 4.02 \\
\hline Palmitic Acid, C16:0 & 21.5 & 21.4 \\
\hline Arachidic Acid, C20:0 & 0.27 & 0.29 \\
\hline Heneicosanoic Acid, C21:0 & 0.09 & 0.10 \\
\hline Behenic Acid, C22:0 & 0.13 & 0.13 \\
\hline Tricosanoic Acid, C23:0 & 0.04 & 0.05 \\
\hline Lignoceric Acid, C24:0 & 0.07 & 0.07 \\
\hline SFA & 32.09 & 32.17 \\
\hline Myristoleic Acid, C1 4:1 & 0.22 & 0.27 \\
\hline Palmitoleic Acid, C16:1 & 8.04 & 7.39 \\
\hline Cis- 11 -Eicosenoic Acid, C20:1 & 0.48 & 0.44 \\
\hline Elaidic Acid, C18: ln9t & 0.18 & 0.18 \\
\hline Oleic Acid, C18:1n9c & 13.24 & 12.74 \\
\hline Nervonic Acid, C24:1 & 0.08 & 0.07 \\
\hline MUFA & 22.24 & 21.09 \\
\hline Linolelaidic Acid, C18:2n9t & 0.24 & 0.23 \\
\hline Linoleic Acid, C18:2n6c & 7.91 & 7.61 \\
\hline v-Linolenic Acid, C18:3n6 & 0.81 & 0.63 \\
\hline Linolenic Acid, C1 8:3n3 & 2.82 & 2.91 \\
\hline Cis-1 1,1 4-Eicosedienoic Acid, C20:2 & 0.35 & 0.33 \\
\hline Eicosetrienoic Acid, C20:3n6 & 0.57 & 0.49 \\
\hline Eicosetrienoic Acid, C20:3n3 & 0.52 & 0.5 \\
\hline Arachidonic Acid, C20:4n6 & 0.87 & 0.78 \\
\hline Docosadienoic Acid, C22:2 & 0.02 & 0.02 \\
\hline Eicosapentaenoic Acid, C20:5n3 & 1.15 & 1.03 \\
\hline Docosahexaenoic Acid, C22:6n3 & 2.89 & 2.84 \\
\hline PUFA & 18.15 & 17.37 \\
\hline Unidentified & 27.52 & 29.37 \\
\hline Total of Fatty Acid & 72.48 & 70.63 \\
\hline
\end{tabular}


Table 2 EPA and DHA contents of fish oil extracted from tilapia by-product and fresh water fishes

\begin{tabular}{|c|c|c|c|c|c|c|}
\hline $\begin{array}{r}\text { Fatty } \\
\text { Acid } \\
\end{array}$ & Fish Oil A & $\begin{array}{l}\text { Fish } \\
\text { Oil B }\end{array}$ & $\begin{array}{c}\text { Oreochromis } \\
\text { niloticus }^{1}\end{array}$ & $\begin{array}{l}\text { Pangasius } \\
\text { pangasius }^{2} \\
\end{array}$ & $\begin{array}{c}\text { Clarias } \\
\text { gariepinus }{ }^{1} \\
\end{array}$ & $\begin{array}{c}\text { Tilapia } \\
\text { zilli }^{1} \\
\end{array}$ \\
\hline EPA & 1.15 & 1.03 & 0.28 & 0.83 & 0.36 & 1.00 \\
\hline DHA & 2.89 & 2.84 & 0.80 & 0.95 & 0.79 & 3.00 \\
\hline
\end{tabular}

Keterangan:

$\mathrm{A}=$ Fish oil extracted from tilapia by-product at $25^{\circ} \mathrm{C}$

$\mathrm{B}=$ Fish oil extracted from tilapia by-product at $70^{\circ} \mathrm{C}$

(1) Osibona et al. (2009); (2) Panagan et al. (2011)

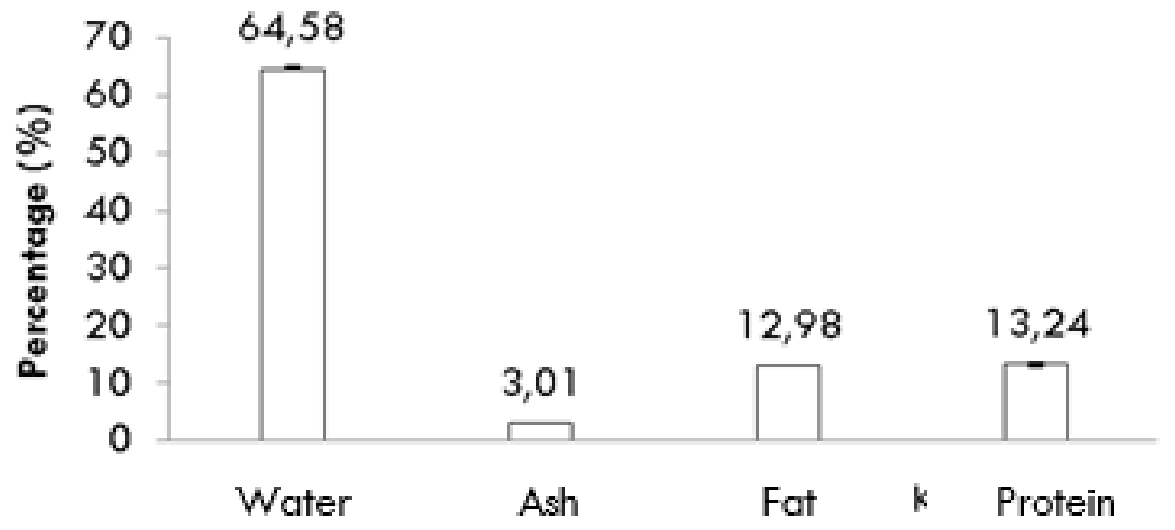

Figure 2 Chemical composition of tilapia (Oreochromis niloticus) by-product

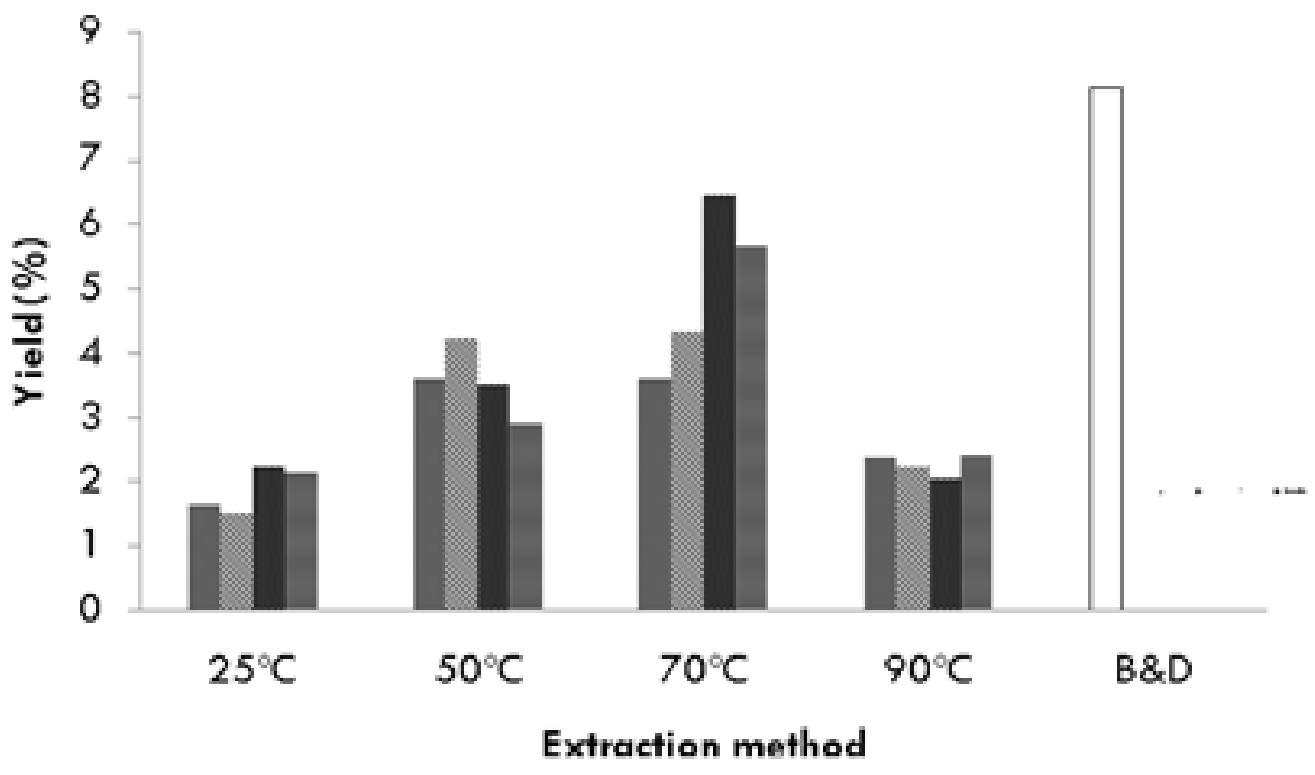

Figure 3 Yield of fish oil from wet rendering extraction dan Bligh and Dyer method.

w 15 minutes, N 25 minutes, \& 35 minutes, $\equiv 45$ minutes, $\square$ Bligh and Dyer extraction method 


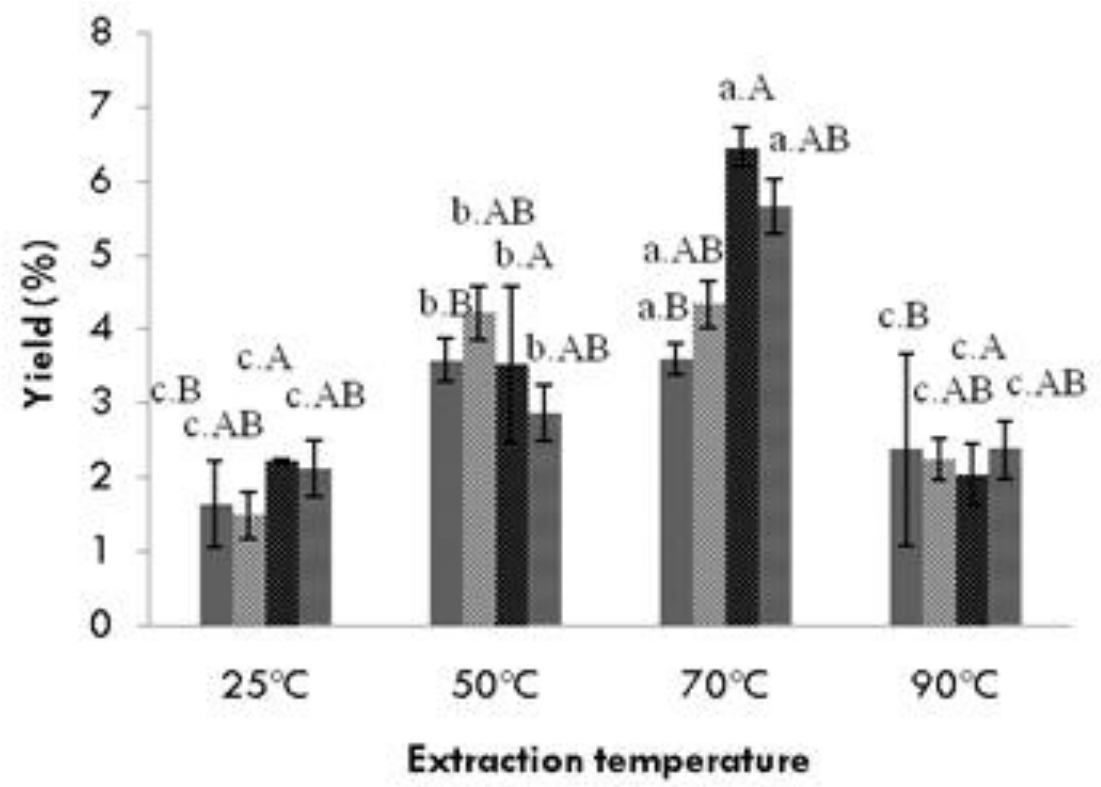

Figure 4 Yield of fish oil as result of 16 combination of extraction period and temperature. $\approx 15$ minutes, $\$ 25$ minutes, $\mathbf{2} 35$ minutes, $\equiv$ 45 minutes

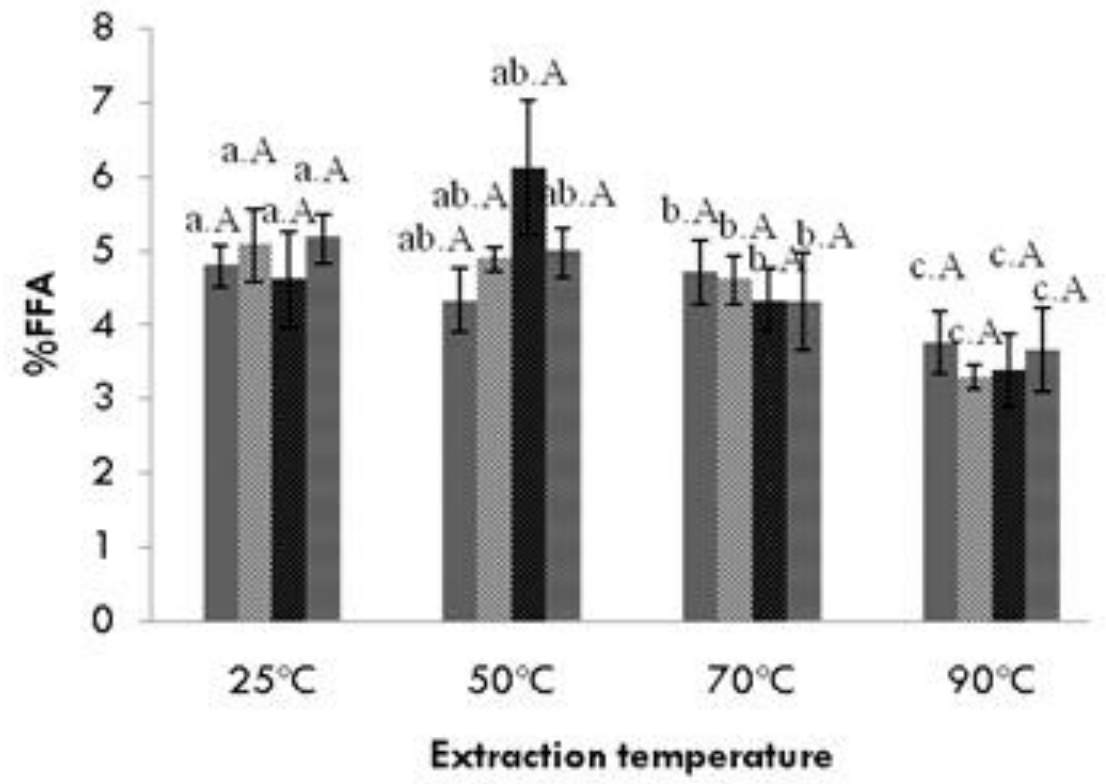

Figure 5 FFA content of fish oil from wet rendering extraction. 15 minutes, $\$ 25$ minutes, 35 minutes, $\equiv 45$ minutes 


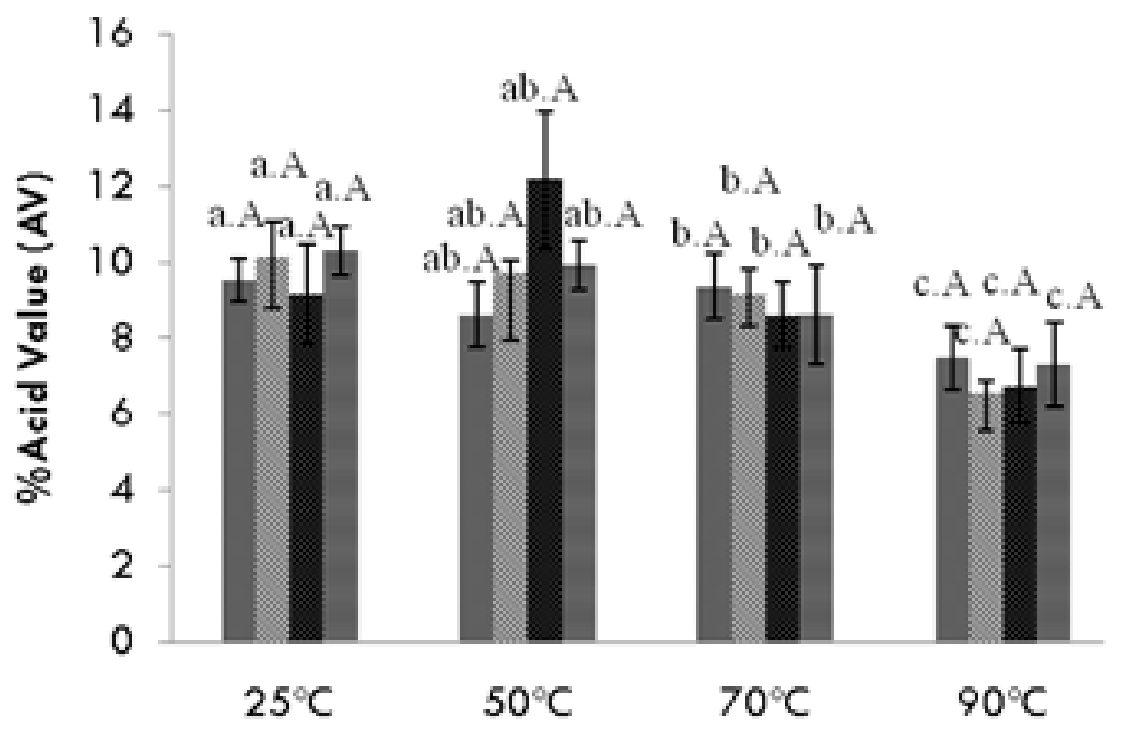

Extraction temperature

Figure 6 Acid value of fish oil from wet rendering extraction. 䋞 15 minutes, $\times 25$ minutes, 100 minutes, $\equiv 45$ minutes

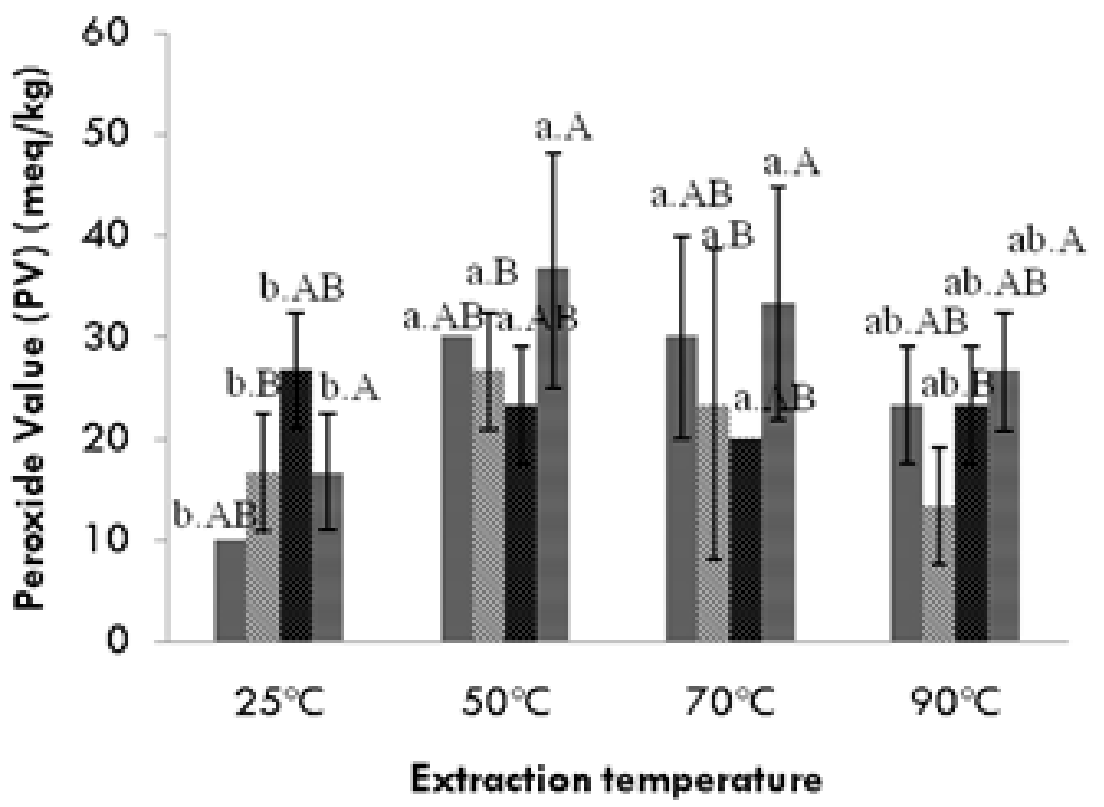

Figure 7 Peroxide value of fish oil from wet rendering extraction. 絡 15 minutes, \& 25 minutes, 35 minutes, $\equiv 45$ minutes 


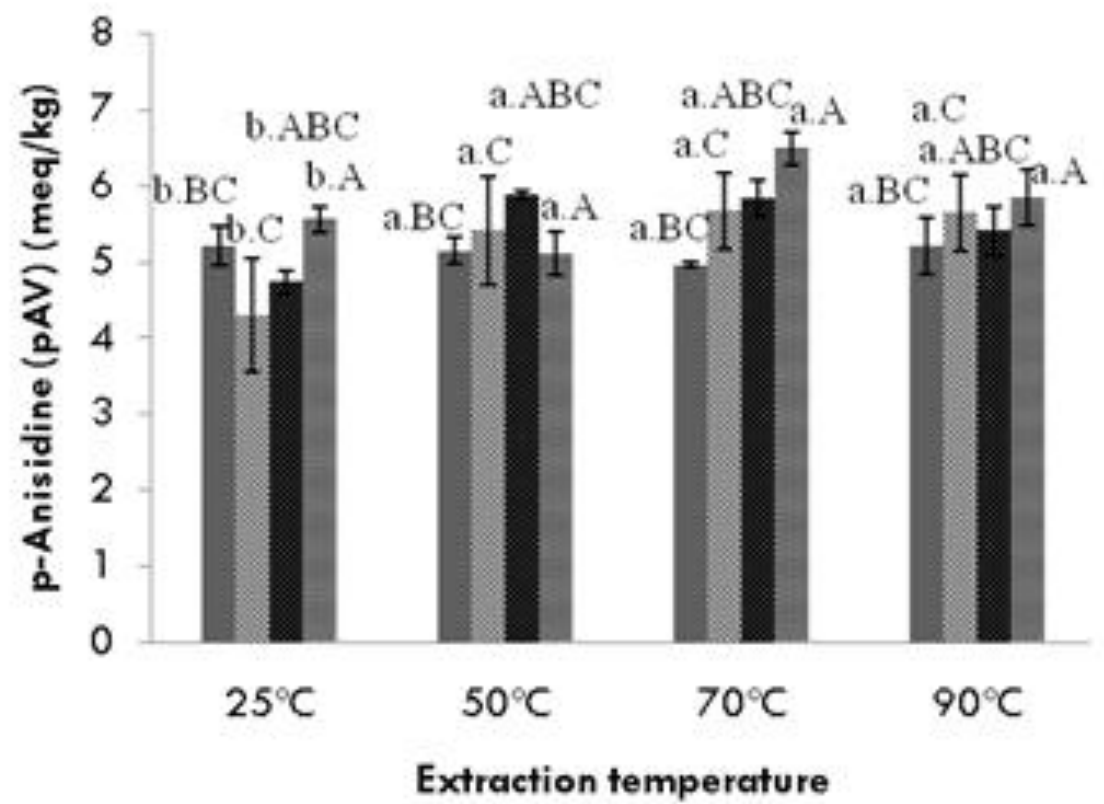

Figure $8 \quad$ P-anisidine value of fish oil from wet rendering extraction. W 15 minutes, « 25 minutes, 35 minutes, $\equiv 45$ minutes

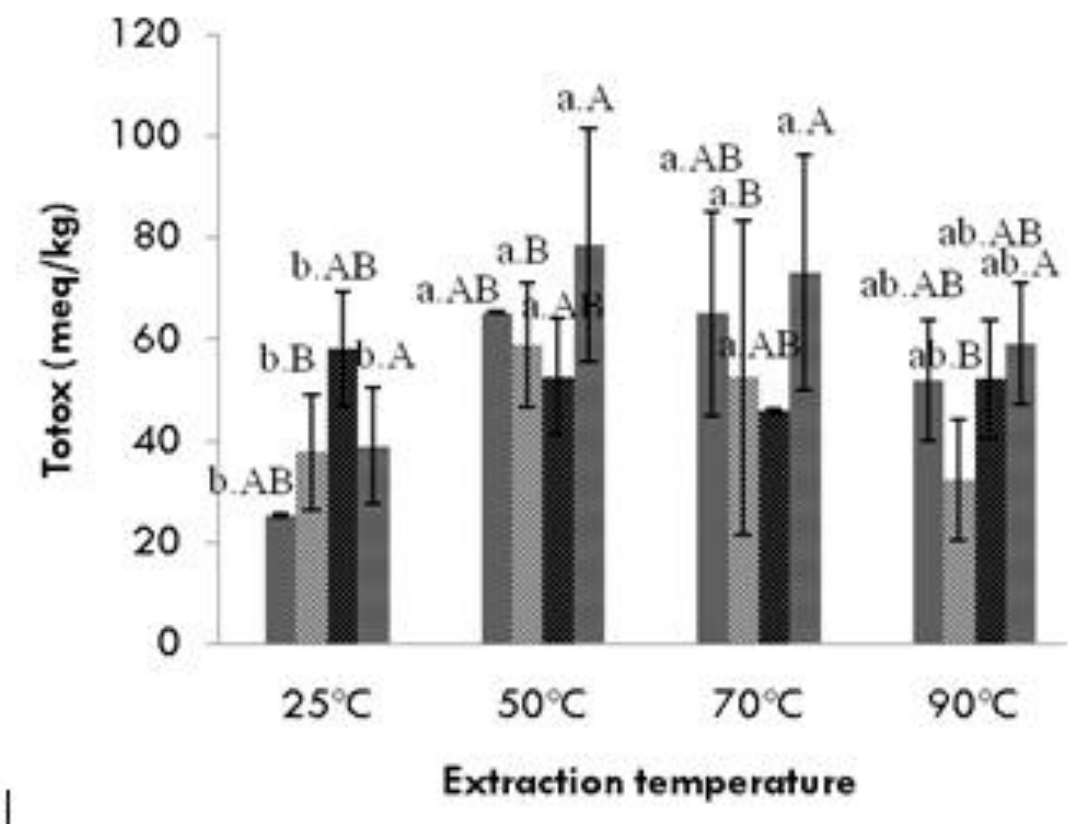

Figure 9 Total oxidation of fish oil from wet rendering extraction. W 15 minutes, $\mathbb{2} 25$ minutes, 35 minutes, $\equiv 45$ minutes 